\title{
Health management of the college student during the COVID- 19 pandemic
}

\author{
Sri Siswati ${ }^{1 *}$, Elsa Giatri $^{2}$, Yolanda Safitri $^{1}$, and Ice Yolanda Puri ${ }^{3}$ \\ ${ }^{1}$ Health Policy and Administration Departement, Faculty of Public Health, Andalas University, Padang, Indonesia \\ ${ }^{2}$ West Sumatra Senses Health Center, Padang,Indonesia \\ ${ }^{3}$ Departement of Dietetics, Faculty of Medicine and Health Science, University of Putra Malaysia
}

\begin{abstract}
In early 2020, the world was hit by the COVID-19 outbreak This virus was originated in Wuhan, China, and hit 216 countries. In Indonesia, there is an increasing trend of data cases on June 11,2020 , as many as 35,295 positive people. This study aims to look at learning and health situations during the pandemic and the health impacts on students. As a result of the pandemic, lecture activities that were originally on campus were moved to homes with a distance learning system. The descriptive research method is authoritative with a sample of 96 students. The results of this study show that during the COVID-19 pandemic, some students experienced health problems as a result of the transition from offline to online learning, such as anxiety, headaches, and fatigue caused by staring at screens for too long and just doing too many assignments. Even though, students are aware of the importance of health protocols and use them, such as social distancing, wearing a mask when outside, and washing their hands. Students affirm that there is an adequate supply of nutritious food. It can be concluded that changes in learning activities have an impact on student's health, but this can be mitigated with good management and adherence to health protocols.
\end{abstract}

\section{Introduction}

The emergence of a new virus, a new strain of Corona (SARS-CoV-2), a condition known as Coronavirus Disease 2019, shook the world in early 2020. (COVID19). The virus's origins were discovered in Wuhan, China, at the end of December 2019 [1].

A mystery incidence of pneumonia was initially reported in Wuhan, Hubei Province, in December 2019. new coronavirus. The disease was initially known as the 2019 novel coronavirus (2019-nCoV), but on February 11, 2020, WHO published a new name for it: Coronavirus Disease (COVID-19), which is caused by the Severe Acute Respiratory Syndrome Coronavirus-2 (SARSCoV-2).

This virus can be transmitted from human to human and has spread widely to 216 countries and is designated as a Pandemic. The Pandemic effect makes all fields experience changes, especially in the field of higher education. According to WHO data, on June 24, 2020, globally, there are 9.296.202 cases and 479.133 deaths, whereas according to Indonesian task force data, on June 24, there are 49.009 cases and 2.573 deaths [2].

A new policy has been implemented by the Ministry of Education and Culture's Directorate of Higher Education No.1 of 2020 concerning the prevention of the spread of COVID-19 in universities, which asks all universities in Indonesia to begin distance learning, or in other words, students must do lessons at home [3].

Many students return to their homes and districts after the university is closed. The socioeconomic diversity, the existence of little resources, regional culture, and an epidemic-plagued atmosphere that is dense with fears is not favorable to learning. The epidemic's current stage, which shows an upward trend in positive cases and deaths, appears to be tense psychologically. Students with particular qualities may be affected to adapt to the learning models and outbreak environment's conditions. Students from low socioeconomic backgrounds, for example, may have restricted housing alternatives for distance learning, limited access to high-speed internet, and significant study requirements. It is not only the facilities that are criticized during online learning, but also the students' health in this Pandemic condition.

Student health and safety are very important. Every day students have to face their laptops or android mobile phones to learn from one lesson to another. Anticipation of being impacted is also influenced by vigilance to wash hands, wear masks and maintain distance if you are to locations that provide internet, electricity, and unstable networks. How can students manage their learning in this distant learning, so that learning runs well and student health and safety are maintained?

\footnotetext{
* Corresponding author: srisiswati@gmail.com
} 
Based on research by Pustikasari, show that online learning uses zoom media. Stress and fatigue in students. Fatigue and stress occur more learning using zoom applications than Goggle class and Whatsapp. Learning media using zoom applications risk 2 times experiencing fatigue in students and 4 times at risk of experiencing stress compared to the use of learning media using Google class and Whatsapp [4].

Research conducted by Rahardjo 2020, that social media as a medium learning that should be used as a stress coping in his research Become a new source of stress and fatigue. Because of social media fatigue. experienced by students who study at home and the role of internet activities has been a lot Take many aspects of an individual's personal life, especially the stress of anxiety related to COVID-19 [5].

The health and safety of students are critical. Students must face their computers or Android mobile phones every day to learn from one lesson to the next. The likelihood of being impacted is also controlled by vigilance in washing hands, wearing masks, and keeping a safe distance from places that offer internet, energy, or unstable networks. How can students manage their learning in this distance learning environment such that learning continues to function smoothly while maintaining student health and safety?

\section{Methods}

This study uses the quantitative approach to descriptive research. This research took place in Padang, Indonesia, in May 2020. The population in this study is made up of students that study online from home using a variety of programs, but the actual population number is unknown. Based on the formula's calculation, the sample size is 96 respondents. The following are some sample criteria: Bachelor, Master, or Doctorate students from public universities or private colleges in Padang City are eligible to apply. Willing to be a respondent, currently learning "study from home," and the exclusion in a preliminary study, criteria are not a sample.

In this study, primary data was collected by filling out a questionnaire that was provided by researchers and related to the questions on the questionnaire. The secondary data has been collected through document review, which also involves gathering information from reports, documents, journals, seminars, and data relating to researchers. related to COVID-19 issues. Data were analyzed using univariate analysis techniques in IBM SPSS Statistic Version 25 to determine the description of learning models as well as the health of specific students. There are a few issues that stand out.

\section{Results and Discussion}

According to the table, the majority of respondents in this study were 90.6 percent women and 9.4 percent men. This condition could be caused by the fact that there are more female students than male college students who fill out the questionnaire.
Table 1. Characteristics of Respondents

\begin{tabular}{|l|c|c|c|}
\hline Variable & Category & $\begin{array}{c}\text { Frequency } \\
\text { (n) }\end{array}$ & $\begin{array}{c}\text { Percent } \\
\text { age } \\
\text { (\%) }\end{array}$ \\
\hline \multirow{2}{*}{ Gender } & Male & 9 & 9.4 \\
\cline { 2 - 4 } & Female & 87 & 90.6 \\
\hline \multirow{2}{*}{ Aged } & $15-20$ & 67 & 69.8 \\
\cline { 2 - 4 } & $21-30$ & 29 & 30.2 \\
\hline
\end{tabular}

The majority of respondents aged 15-20 years were 69.8 percent, while those aged 20-30 years were 30.2 percent. At the age of 15-20 years, the age condition is relatively severe. It is estimated that students who completed the questionnaire had undergraduate education, with one-third of the respondents being undergraduate, postgraduate, or doctoral students. Filling out circulated questionnaires shows the respondents' interest in participating in online or online learning.

Table 2. Condition of a college student during COVID-19 pandemic

\begin{tabular}{|c|c|c|c|}
\hline Variable & Category & $\begin{array}{l}\text { Frequency } \\
\text { (n) }\end{array}$ & $\begin{array}{c}\text { Percentage } \\
(\%)\end{array}$ \\
\hline \multirow[t]{2}{*}{ Anxiety } & Anxiety & 82 & 85.5 \\
\hline & No Anxiety & 14 & 14.5 \\
\hline \multirow{3}{*}{$\begin{array}{l}\text { Health } \\
\text { Condition }\end{array}$} & Healthy & 87 & 91 \\
\hline & Unwell & 8 & 8 \\
\hline & $\begin{array}{c}\text { People } \\
\text { under } \\
\text { surveilence } \\
\end{array}$ & 1 & 1 \\
\hline \multirow{2}{*}{$\begin{array}{l}\text { Headaches } \\
\text { and Fatigue }\end{array}$} & Yes & 60 & 62 \\
\hline & No & 36 & 38 \\
\hline
\end{tabular}

According to the data table above, 85.5 percent of those who learned online were anxious, while 14.5 percent were not. Anxiety in learning can be caused by a variety of issues, including the COVID 19 pandemic situation, the existence of multiple tasks, and the difficulties of online learning that must be attempted. According to research, anxiety arises as a result of uncertainty about the possibility of future threats, affecting a person's ability to avoid or manage the effects of these threats. This also applies to students. It's a good way to begin the day.

According to the data in the table above, 91 percent of the students feel physically and mentally healthy. Students may be able to learn as a result of this condition. People who are asymptomatic during a pandemic may be uncertain of the severity of the COVID 19 outbreak. Compliance with health protocols is an important measurement. Students' health is raised by medical personnel who take their body temperature, blood pressure and perform a general examination.

The table above showed whether or not students suffer from headaches. The majority of students, 62 percent, experienced headaches and fatigue, while 38 percent did not experience headaches or fatigue. According to Pustikasari and Fitriyani's research, the relationship between fatigue and online learning media using zoom has a p-value of 0.019. Using the OR value of 0.019 The study concluded that there is a significant relationship between fatigue and online learning media using zoom. 
When using an online learning application, a student is twice as likely to experience fatigue as when learning with Gcr+Wa media [4].

Table 3. Adequacy of nutritious food

\begin{tabular}{|l|l|c|c|}
\hline Variable & Category & $\begin{array}{c}\text { Frequency } \\
\text { (n) }\end{array}$ & $\begin{array}{c}\text { Percentage } \\
(\%)\end{array}$ \\
\hline $\begin{array}{l}\text { Nutrition } \\
\text { Food }\end{array}$ & Enough & 92 & 95.8 \\
\hline & Not Enough & 3 & 4.2 \\
\hline
\end{tabular}

The nutritional condition of students can be seen from the adequacy of food, with 95.8 percent believing it was sufficient and less than 5 percent believing it was insufficient. Food adequacy does not represent balanced nutrition, because an adequate balance of carbohydrates, animal and vegetable protein, fruits, and vegetables is needed.

According to research, who studied changes in body weight and eating habits during the COVID-19 pandemic, $1.5 \mathrm{~kg}$ is affected by lack of exercise boredom/loneliness/anxiety/depression, increased eating, more snack consumption, and do not consume highly nutritious foods. Diet and dietary habits produce results. There is a significant relationship between body mass index and energy intake, as well as the nutritional status of students who eat processed foods [6].

Table 4. Health protocols

\begin{tabular}{|c|c|c|c|}
\hline Variable & Category & $\begin{array}{c}\text { Frequenc } \\
\mathbf{y} \\
(\mathbf{n}) \\
\end{array}$ & $\begin{array}{c}\text { Perce } \\
\text { ntage } \\
(\%) \\
\end{array}$ \\
\hline \multirow[t]{2}{*}{$\begin{array}{l}\text { Social } \\
\text { Distancing }\end{array}$} & $\begin{array}{c}\text { Implemente } \\
\mathrm{d}\end{array}$ & 87 & 90.6 \\
\hline & Not vet & 9 & 9.4 \\
\hline \multirow{2}{*}{$\begin{array}{l}\text { Using Mask } \\
\text { When } \\
\text { Outside the } \\
\text { House }\end{array}$} & Yes & 90 & 91 \\
\hline & No & 6 & 8 \\
\hline \multirow{2}{*}{$\begin{array}{l}\text { Wash hands } \\
\text { with soap }\end{array}$} & Yes & 61 & 63.6 \\
\hline & No & 35 & 36.4 \\
\hline \multirow[t]{2}{*}{$\begin{array}{l}\text { Adequacy } \\
\text { of Sleep } \\
\text { Times }\end{array}$} & Enough & 66 & 68.8 \\
\hline & Not Enough & 30 & 31.2 \\
\hline \multirow[t]{2}{*}{$\begin{array}{l}\text { Vitamins/Su } \\
\text { pplements }\end{array}$} & Available & 61 & 63.3 \\
\hline & Inavailable & 35 & 38.7 \\
\hline
\end{tabular}

To prevent the spread of the COVID 19 outbreak, three indicators are used. Most students follow health protocols, which include 90.6 percent social distancing, 86 percent wearing masks, and 63.6 percent washing their hands with soap under certain conditions. When students don't get a good signal in their place of residence, they wear a mask and look for a signal network outside their home or residence. It is critical to use face masks correctly. The entire face, from the bridge of the nose to the chin, must be covered by a face mask. Before applying and removing the face mask, wash your hands with soap and water or an alcohol-based hand sanitizer. Remove the face mask from the back, avoiding touching the skin, and Throw away the face mask safely once used.
During this period of the pandemic, the Indonesian government's social distancing policy is expected to reduce and control the spread of the COVID-19 virus. Learning and working from home, staying at home and avoiding contact, prohibiting excessive activity, and limiting operating hours in public places are all policies that promote social distancing. To reduce COVID-19 cases, the government, which previously promoted efforts to promote social distancing (restrictions on social distancing), is now tightening its grip on physical distancing or maintaining physical distance from other people $[7,8]$. Many factors affected compliance, including knowledge, motivation, perception, and belief in disease control and prevention efforts, environmental variables, the quality of health instruction, and the ability to access available resources.

Adequate sleep is one sign of a healthy body. The majority of respondents, 68.8 percent, reported getting enough sleep for at least 7 hours, while 31.2 reported not getting enough sleep for 7 hours. This is consistent with the findings of a survey conducted by the Biology Center for Chronobiology, Psychiatric Hospital of the University of Basel, which found that respondents, on average, slept 15 minutes longer at night during the pandemic, and while there is a decrease in sleep quality, it is recommended that students' sleep patterns improve during the pandemic. Improving sleep patterns in students during the pandemic COVID-19 is beneficial to their health. The reason for this is a lack of sleep and an irregular sleep schedule can lead to a variety of health problems varying from weight gain to diabetes, depression, and anxiety disorders [9].

According to the survey results of participants who participated in the online learning process while working from home during the COVID 19 pandemic, the majority had already implemented it. Part of it has not been addressed and may be the result of a lack of careful planning for safety and health during the learning process. The number of courses taken does not have a plan for health protection in the event of a COVID-19 outbreak.

Preparation of medicine or vitamin at home is necessary during this COVID-19 due to diseases that can be overcome without going to a health care facility, as it reduces mobilization and crowding, resulting in a limited spread of COVID-19. During this pandemic, the following medications must be prepared at home: paracetamol, antihistamines, decongestant, cold medicine, and digestive medicine.

During the COVID-19 pandemic, nutritional adequacy, especially vitamins and minerals, is needed in maintaining 65 optimal immune systems, vegetables and fruits are sources of vitamins, minerals, and fibre. Vitamins and minerals contained in vegetables and fruits act as antioxidants and help increase immunity. By increasing immunity the body can help in the prevention of COVID-19 outbreaks [10].

Since the outbreak of the COVID-19 pandemic, so many recommendations to consume supplements or vitamins for endurance improvement. A supplement is a product that contains one or more vitamins, minerals, amino acids, fatty acids, and fiber. Supplements are not a complete food substitute but we still need to consume a wide variety of healthy foods to meet our daily needs.[10] 
COVID-19 pandemic and supplement use endurance maintenance, coefficient numbers These findings show a positive correlation. 0.175 , indicating that the correlation is unidirectional. As a result, there is little chance that COVID-19 is now better understood. The utilization of power maintenance supplements The resistance of the body is increasing [10]. Six factors influence supplement use and they are as follows: Level of education, experience, age of accumulation, beliefs, information, and income [11].

The authors would to thank college students as respondents to this research, thanks to the reviewer for their valuable comments to revise the paper.

\section{Conclusions and Recommendations}

Online learning is one alternative that can be done when the situation is not possible to be on campus and face to face. Efforts to improve online learning capacity have been carried out by various universities as evidenced by the existence of an online learning platform developed by each university with different names and models. In addition, several companies have also developed this online learning platform and can be accessed easily. But not all the technology that is.

\section{References}

1. Y Yuliana. Corona virus disease (COVID-19): A literature. Health Heal Ma, 2(1):187-92 (2020)

2. COVID Control Cluster Team. Latest COVID Data (2020)

3 Ministry of Education and Culture of the Republic of Indonesia. Circular of the Minister of Education and Culture of the Republic of Indonesia Number 36962/MPK.A/HK/2020. Minister of Education and Culture of the Republic of Indonesia [Internet]. 2020;1-2. Available from: https://www.kemdikbud.go.id/main/index.php/files/ download/c5d9f0ec9ff40c6 (2020)
4. A. Pustikasari, L. Fitriyanti. Stress and Zoom Fatigue on Students During Online Learning During the COVID-19 Pandemic. J Health Sciences, 13(1):2537 (202)

5. W. Rahardjo, N. Qomariyah, I. Mulyani, I. Andriani , Social media fatigue in college students during the COVID-19 pandemic: The role of neuroticism, information overload, life invasion, anxiety, and gender. Social Psychology, 18(59):12 (2020)

6. C.J.E. Rambing, A.S.L. Bolang, S.E.S. Kawengian, Energy Intake and Nutritional Status of Students During the COVID-19 Pandemic J Biomedicine Jbm, 13(2):175-9 (2021)

7. Yanti B, Wahyudi E, Wahiduddin W, Novika RGH, Arina YMD, Martani NS, et al. People's Knowledge, Attitudes, and Behaviors towards Social Distancing Policies as a Prevention of COVID-19 Transmission in Indonesia. J Adm Indonesian Health 8(2):4 (2020)

8. Lathifa AR, Kamalia F, Putra FP, ... Student Compliance in Implementing Health Protocols during the COVID-19 Pandemic Period. Processing Inter [Internet].1(1):1-8. Available from: https://press.umsida.ac.id/index.php/iiucp/article/vie w/598 (2021)

9. C. Blume. Since January 2020 Elsevier has created a COVID-19 resource center with free information in English and Chinese about the novel coronavirus COVID-19. The COVID-19 resource center is hosted on Elsevier Connect, the company's news and public information, (January). (2020)

10. K. Lidia, E. Levina, S. Setianingrum, C. Folamauk, M. Riwu, A. Lidesna, et al. Health Improvement with Supplements and Balanced Nutrition in the Era of the COVID-19 Pandemic J Lemb Service to Masy Undana [Internet]. 14(2):63-8. Available from: http://ejurnal.undana.ac.id/jlppm/article/view/3445 (2020)

11. S. Notoatmodjo. Health promotion and health behavior. Jakarta: Rineka Cipta (2012) 